\title{
Effectiveness of Natural Coagulant in Coagulation Process: A Review
}

\author{
Amir Hariz Amran ${ }^{1 *}$, Nur Syamimi Zaidi ${ }^{1}$, Khalida Muda $^{1}$, Liew Wai Loan ${ }^{2}$ \\ ${ }^{1}$ Faculty of Civil Engineering, Universiti Teknologi Malaysia, 81310 Skudai, Johor, Malaysia \\ ${ }^{2}$ UTM School of Professional and Continuing Education (UTMSPACE), 81310 Skudai, Johor, Malaysia \\ *Corresponding E-mail: amir94hariz@gmail.com:
}

\begin{abstract}
Natural coagulants have been increasingly popular in the past few years due to its benefits and the fact that it resolves most of the associated problems when using chemical coagulants. Plant-based natural coagulants perform coagulation either by polymer bridging or charge neutralization, it can be extracted from various plant components. Concerted research and development efforts have been conducted in discovering new plant species and constituents that can be used as natural coagulants, which further boosting the effectiveness of existing plant-based natural coagulants. The objective of this paper is to provide a mini review on studies done over the span of ten years regarding plant-based natural coagulants. This paper also includes advantages and disadvantages of natural coagulants prior to identify several potential research gaps to provide platform towards the need of further study.
\end{abstract}

Keywords: Natural coagulant; polymer bridging; charge neutralization; advantages; disadvantages; research gap.

\section{Introduction}

Coagulation and flocculation processes are widely used in water and wastewater treatment. Its main objective is to remove suspended colloidal particles and to reduce turbidity in water body [1]. The process usually takes place in a chemical reactor in which the influent water or wastewater enter the basin and it is mix with coagulant agents using a mechanical mixer, followed by sedimentation process to remove the particulate through gravity settling [2]. There are many types of coagulants available. The most often used are the chemical-based coagulants such as alum and ferric salts [3]. However, the use of these chemical coagulants resulted in many downsides such as harmful voluminous sludge production [3]. There are also coagulants derived from plant-based materials known as natural coagulant. Natural coagulants are safe and ecofriendly [1] It can be extracted from plant, microorganisms and animals [3]. Some of the plants are able to be a coagulant because they are able to conduct some of the coagulation mechanisms which are neutralizing the charge in colloidal particles and perform polymer bridging [4].

\section{Mechanism of Natural Coagulant}

There are mainly four types of coagulation mechanisms which are double layer compression, polymer bridging, charge neutralization and sweep coagulation. However, only polymer bridging and charge neutralization are the possible coagulation mechanisms for plant-based natural coagulant [4]. Polymer bridging is preceded by polymer adsorption which is a process where long chain polymers attach itself to the colloidal particle's surface because of the affinity present between them. Only some part of the polymers is attach to the particle while the unattached parts will form loops and tails
[5]. These loops and tails are the main structure of polymer bridging because it allows attachments to other colloidal particles and thus forming larger flocs as shown in Figure 1. Therefore, sufficient unoccupied particle surface is needed to gain effective polymer bridging and the bridging must span far enough to overcome the interparticle repulsion. These conditions are met by adding sufficient dosage of polymer through natural coagulant which it provides enough bridging links and bare particle surface for strong polymer bridging [6].

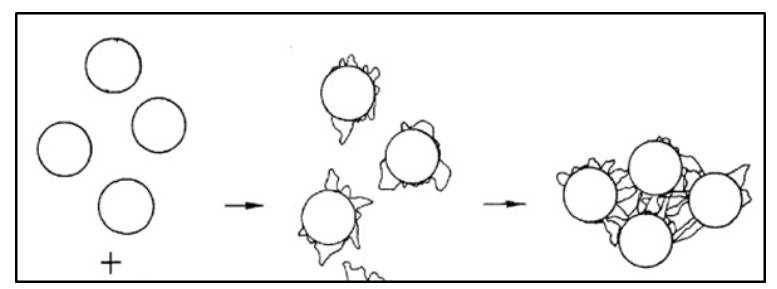

Figure 1. The illustration of a bridging mechanism in coagulation [6]

Charge neutralization mechanism uses ionisable polymer (polyelectrolytes) as coagulant to stabilize the colloidal particle. Colloidal particles are negatively charged and that causes them to repel one another. Therefore, polycation are 
used to stabilize the particles, gaining near to zero zeta potential. Charge density of the polyelectrolyte will determine the optimum dosage of polyelectrolyte needed because higher charge density corresponds to lower coagulant dosage [5]. The basis of charge neutralization is that the adsorption of high charge density polyelectrolytes by low charge density colloidal particles occurs in a 'patch wise' manner. This is called electrostatic patch mechanism (Figure 2), meaning that the particle's surface having patches of positive and negative regions. These regions cause additional attraction between particles given that the opposite charged regions are properly aligned.

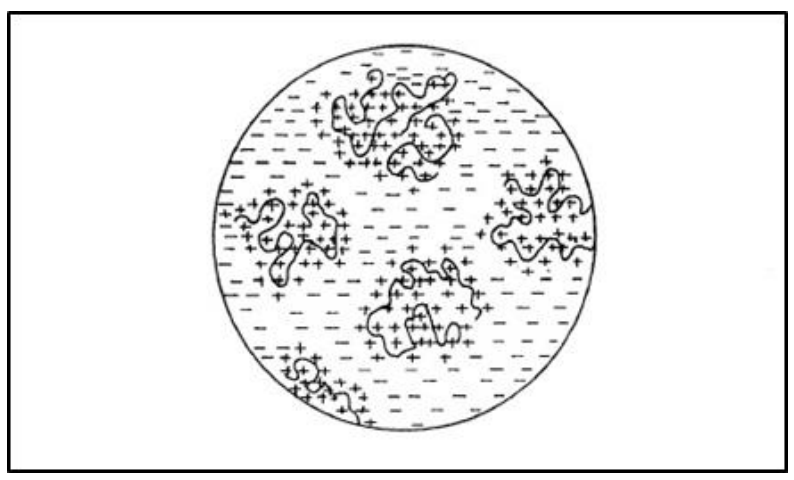

Figure 2. The electrostatic patch model in a charge neutralization mechanism [6]

Table 1. Recent studies on plant-based natural coagulant

\section{Types of Natural Coagulant}

Plant-based coagulants have various categories. However, this

\subsection{Plants Containing Starch}

Starch is made up of amylose and amylopectin, it is categorized as polysaccharide [4]. Starch have low efficiency if it is used as a coagulant on its own, therefore it is often modified to cationic starch derivatives to increase its efficiency. Cationic starch uses charge neutralization to stabilize highly negatively charged colloidal particles in water bodies [7]. A recent study on grafting polymerization of starch was done by Liu et al. [8]. Corn starch (St) was grafted together with 3-Chloro-2hydroxypropyltrimethylammonium chloride (CTA) to four different ratios (St:CTA) to remove kaolin, Escherichia coli and Staphylococcus aureus from water samples. The obtained results can be seen from Table 1 that 1:1 ratio is the optimum ratio with removability up to $98 \%$ for all parameters. In another study by Choy et al. [9] was shown in Table 1 regarding the combination of starch and chemical coagulant to treat kaolin suspended water. The study showed that autoclaved rice starch alone can remove $50 \%$ of kaolin at a dosage of $120 \mathrm{mg} / \mathrm{L}$ and $\mathrm{pH}$ of 4 , however kaolin removal can increase up to $78 \%$ by adding a second step coagulation using $\mathrm{PACl}$. Another study investigates on microalgae harvesting

using rice starch coagulant by Yan et al. [11] was done and resulted to $80 \%$ of microalgae removal in 30 minutes of sedimentation at $\mathrm{pH}$ of 4 and $120 \mathrm{mg} / \mathrm{L}$ dosage added.

\subsection{Fruit Wastes}

In a research done by Yang et al. [25] shown in Table 1, investigates the efficiency of using banana pith as natural polyelectrolyte to treat polluted river water. From the research, banana pith was able to remove more than $80 \%$ of turbidity, sulphates, nitrates, lead, zinc, iron, chromium and copper. Those efficiencies are achieved at an optimum dosage of $0.1 \mathrm{~kg} / \mathrm{m}^{3}$ and at a $\mathrm{pH}$ of 4 .

\begin{tabular}{|c|c|c|c|c|}
\hline \multirow[t]{2}{*}{ Type of Coagulant } & \multicolumn{2}{|c|}{$\begin{array}{l}\text { Operating } \\
\text { conditions }\end{array}$} & \multirow[t]{2}{*}{ Findings } & \multirow[t]{2}{*}{ Ref. } \\
\hline & $\mathrm{pH}$ & dosage & & \\
\hline Moringa oleifera & $\begin{array}{l}5-7 \\
- \\
7 \\
7.5 \\
7\end{array}$ & $\begin{array}{l}2-3 \mathrm{~g} / \mathrm{L} \\
20 \mathrm{mg} / \mathrm{L} \\
50 \mathrm{mg} / \mathrm{L} \\
50 \mathrm{mg} / \mathrm{L} \\
250 \mathrm{mg} / \mathrm{L}\end{array}$ & $\begin{array}{l}54 \% \text { of TSS removal for coffee fermented wastewater } \\
\text { Iron nano particles synthesizes with } \mathrm{MO} \text { leaf extract, } 85 \% \text { of nitrate } \\
\text { removal } \\
85 \% \text { of Chlorophyll a and turbidity removals } \\
84 \% \text { turbidity and } 88 \% \text { E. coli removal } \\
99 \% \text { of turbidity removal using } \mathrm{MO}-\mathrm{NaCl}\end{array}$ & $\begin{array}{l}{[18]} \\
{[19]} \\
{[17]} \\
{[15]}\end{array}$ \\
\hline $\begin{array}{l}\text { Roselle } \\
\text { seeds }\end{array}$ & $\begin{array}{l}4 \\
10\end{array}$ & $\begin{array}{l}40 \mathrm{mg} / \mathrm{L} \\
60 \mathrm{mg} / \mathrm{L}\end{array}$ & $\begin{array}{l}93 \% \text { turbidity removal for synthetic wastewater } \\
87 \% \text { turbidity removal for industrial wastewater }\end{array}$ & [2] \\
\hline Carica papaya & - & $\begin{array}{l}100 \mathrm{seeds} / \\
100 \mathrm{~L} \\
0.4 \mathrm{~g} \\
/ 200 \mathrm{ml}\end{array}$ & $\begin{array}{l}88 \% \text { E. coli bacteria and } 90 \% \text { turbidity removed from surface water. } \\
80 \% \text { of methylene blue dye removal }\end{array}$ & $\begin{array}{l}{[22]} \\
{[24]}\end{array}$ \\
\hline Banana pith & 4 & $0.1 \mathrm{~kg} / \mathrm{m}^{3}$ & $\begin{array}{l}80 \% \text { of turbidity, sulphates, nitrates, lead, zinc, iron, chromium and } \\
\text { copper removal }\end{array}$ & [25] \\
\hline Orange peel & 7.5 & $0.2 \mathrm{~g} / \mathrm{L}$ & $97 \%$ turbidity removal from dairy wastewater & [13] \\
\hline Jackfruit & - & $60 \mathrm{mg} / \mathrm{L}$ & $43 \%$ of turbidity removed from kaolin water & [10] \\
\hline Osimum basilicum & 7.7 & $1.6 \mathrm{mg} / \mathrm{L}$ & $\begin{array}{l}68.5 \% \text { of color and } 61.6 \% \text { COD removal from model textile } \\
\text { wastewater }\end{array}$ & [23] \\
\hline Margaritarea discoidea & - & $10 \mathrm{ml} / \mathrm{L}$ & $98 \%$ of turbidity removal from synthetic turbid water & [14] \\
\hline Jatropha curcas & 3 & $120 \mathrm{mg} / \mathrm{L}$ & JCSC-NaCl removed $99 \%$ of turbidity in synthetic wastewater & [23] \\
\hline Plantago ovata & 7 & $0.25 \mathrm{mg} / \mathrm{L}$ & $99 \%$ of turbidity removal & [20] \\
\hline Maerua decumbent & $5-7$ & $\begin{array}{l}0.8-1.2 \\
\mathrm{~kg} / \mathrm{m}^{3}\end{array}$ & $\begin{array}{l}99.2 \% \text { turbidity, } 78.6 \% \text { COD, } 100 \% \text { lead, and } 99.9 \% \text { chromium re- } \\
\text { moval from paint industry wastewater }\end{array}$ & [12] \\
\hline Phaseolus vulgaris & 7 & $1 \mathrm{ml} / \mathrm{L}$ & $\begin{array}{l}\text { Extraction with } \mathrm{NaCl} \text { obtained } 95 \% \text { turbidity removal from kaolin } \\
\text { turbid water }\end{array}$ & [15] \\
\hline Rice starch & $\begin{array}{l}3 \\
4\end{array}$ & $\begin{array}{l}120 \mathrm{mg} / \mathrm{L} \\
120 \mathrm{mg} / \mathrm{L}\end{array}$ & $\begin{array}{l}80 \% \text { of microalgae removal in } 30 \text { minutes } \\
50 \% \text { of kaolin removal, increase up to } 78 \% \text { by adding a second step } \\
\text { coagulation using PACl }\end{array}$ & $\begin{array}{c}{[11]} \\
{[9]}\end{array}$ \\
\hline Corn starch & 4 & $0.5 \mathrm{mg} / \mathrm{L}$ & $98 \%$ removal of kaolin, Escherichia coli and Staphylococcus aureus & [8] \\
\hline
\end{tabular}

paper will only cover starch containing plants, legumes and fruit wastes [7]. The natural polymer contains in the plants are the reason these coagulants can perform such coagulation mechanism. Table 1 shows the recent study that has been done on plant-based natural coagulant in the past 10 years.
Orange peel is another fruit waste that have been investigated for its potential use as coagulant. A study by Anju [13] focus on the treatment of dairy wastewater by using orange peel and comparing it to alum. Dairy wastewater used was stated to have an initial turbidity of 260 NTU but then reduced to 8 NTU by using orange peel powder as coagulant. However, the use of alum achieved a 
higher removal efficiency which is $98 \%$, it is clearly that orange peel has the potential to be used as a natural coagulant. A recent research done by Oladoja et al. [14] experimented on using Margaritarea discodea seeds extract to treat synthetic turbid water. Margaritarea discodea seeds extract contains a coagulating agent called galactomannans, a non-ionic and water-soluble polysaccharide, therefore it uses bridging coagulation mechanism. From Table 1 , the seeds extract manages to remove up to $98 \%$ of turbidity by using $10 \mathrm{ml} / \mathrm{L}$ of dosage. However, the treated water exhibited a green colour and it increases with increase coagulant dosage possibly caused by the greenish colour of the seeds extract. Jackfruit seeds starch have been utilized as natural coagulant by Choy et al. [10] due to its high starch content (54g of starch per $100 \mathrm{~g}$ of seed). The starch was isolated by alkaline extraction and tested for its effectiveness in removing kaolin suspension. It manages to remove $43 \%$ of turbidity in 20 minutes with a dosage of $60 \mathrm{mg} / \mathrm{L}$. Even though the results are mediocre, the starch however are not modified, and no analysis was done to uncover the suitable $\mathrm{pH}$ for the jackfruit seed starch coagulant. Starch has also been studied to aid in microalgae harvest by coagulation. Choy et al. [10] stated that microalgae harvest by alum at $2.1 \mathrm{mg} / \mathrm{L}$ dosage can be enhanced by $25 \%$ by the addition of $60 \mathrm{mg} / \mathrm{L}$ jackfruit seed starch.

\subsection{Legumes}

Table 1 shows that moringa oleifera has been studied by many researchers in the past years. Moringa oleifera contain high value of globulin and albumin protein fraction which greatly contribute to its coagulation ability [16]. Recently Moringa oleifera have been tested to treat coffee fermentation wastewater [18] resulting to $54 \%$ of TSS removal at $\mathrm{pH} 5-7$ with $2-3 \mathrm{~g} / \mathrm{L}$ of dosage. A recent study by Katata-seru et al. [19] synthesised Moringa oleifera seed extract with iron chloride solution ultimately increase the removal percentage of nitrate from ground and surface water to $85 \%$. A study on the oil extraction of Moringa oleifera seeds and its effectiveness at different turbidity was done by [17]. The research discovered that oil extraction is not necessary when using Moringa oleifera as natural coagulant and it performed better in removing Chlorophyll A and turbidity in high turbid water. Table 1 also unveil that many legumes have the potency to be a natural coagulant. A study by Muthuraman and Sasikala [15] investigates the turbidity removal using Phaseolus vulgaris seed-derived coagulant in synthetic turbid water. It is discovered that extraction by using sodium chloride $(\mathrm{NaCl})$ increases the turbidity removal reaching $80 \%$ compared to extraction by distilled water that can only reached $45 \%$ of removal. The study also compared Phaseolus vulgaris to Moringa oleifera seed-derived coagulant whereas it outperformed Phaseolus vulgaris by reaching 99\% of turbidity removal with the same protein extraction process.

\section{Advantages and Disadvantages of Natural Coagulant}

Natural coagulant gains the advantage over chemical coagulant due to various reasons. One of the reasons are natural coagulant are safer than chemical coagulant. When using coagulant for water treatment, there will be possibilities of residue coagulant present in the water after the treatment. Chemical coagulant residue such as alum is harmful because it can cause Alzheimer disease if consumed [18]. On the other hand, if natural coagulant was used, the residual coagulant would not be harmful. Likewise, natural coagulant is much cheaper compared to chemical coagulant. Chemical coagulant such as alum, need coagulant aid to effectively treat high turbidity water, thus making it more expensive and difficult to be used in poor countries. Whereas natural coagulants are much cheaper and can be extracted from various plant wastes which greatly reduce the treatment cost [26]. Nevertheless, an abundance and locally available resource must be met to use natural coagulant commercially. Natural coagulant also has some disadvantages. Using natural coagulant will increase the organic matter present in the water, thus increasing microbial activity. Consequently, additional chlorine should be used to sanitize the treated water [27]. Besides that, natural coagulant such as Moringa oleifera need longer sedimentation time than chemical coagulant [28] and although some coagulant has antibacterial property that can treat E. coli infested water, the removal efficiency is not complete, thus secondary bacterial growth risk could occur [28].

\section{Research Gap}

Over the past several years there have been numerous research studies conducted concerning plant-based natural coagulants. However, several potential research gaps were identified regarding certain aspects of natural coagulants in water and wastewater treatment processes. One of these is the relationship between increase in organic matter and chlorine use. As mentioned previously, using natural coagulants will inevitably result in an increase production of organic matters in the treated water and consequently encourage microbial activity which in turn would require higher chlorine use. However, limited documentation of how these parameters influence one another is available. Besides, use of natural coagulants are said to be cheaper than applying chemical coagulants, but an increase in chlorine use could possibly increase the cost of water treatment. This is rather an assumption as no research has been done regarding this matter. Furthermore, not much research has been done regarding the toxicity of the sludge produced from natural coagulant. As discovered form previous researched, natural coagulant can be extracted from many different sources and it is possible that the sludge produced could differ because the sludge is depended on the type of coagulant used [2].

\section{Conclusion}

In conclusion, there is a necessity to carry out studies to obtain more information on plant-based natural coagulants subjected to its potential application in treating water and wastewater. It also can be confirmed that most of the natural coagulants derived from plant-based materials possessed high potential ability in removing common parameter such as turbidity.

\section{References}

[1] Choy, S. Y., Prasad, K. M. N., Wu, T. Y., Raghunandan, M. E., \& Ramanan, R. N. (2014). Utilization of plant-based natural coagulants as future alternatives towards sustainable water clarification. Journal of Environmental Sciences (China), 26(11), 2178-2189.

[2] Hammer, M.J. and Hammer, Jr. M.J. (2004). Water and Wastewater Technology In: Wastewater Processing. (5th ed). Pearson Prentice Hall: Ohio.

[3] Fathinatul, N., \& Nithyanandam, R. (2014). Wastewater Treatment by using Natural Coagulant. 2nd Eureca, 2-3.

[4] Kristianto, H. (2017). The Potency of Indonesia Native Plants as Natural Coagulant: a Mini Review. Water Conservation Science and Engineering, 2(2), 51-60.

[5] Bolto, B., \& Gregory, J. (2007). Organic polyelectrolytes in water treatment, 41, 2301-2324.

[6] Tripathy, T., \& De, B. R. (2006). Flocculation: A New Way to Treat the Waste Water, 10, 93-127.

[7] Oladoja, N. A. (2015). Headway on natural polymeric coagulants in water and wastewater treatment operations. Journal of Water Process Engineering, 6, 174-192.

[8] Liu, Z., Huang, M., Li, A., \& Yang, H. (2017). Flocculation and antimicrobial properties of a cationized starch. Water Research, 119 57-66.

[9] Choy, S. Y., Prasad, K. N., Wu, T. Y., Raghunandan, M. E., \& Ramanan, R. N. (2016). Performance of conventional starches as natural coagulants for turbidity removal. Ecological Engineering, 94, 352-364.

[10] Choy, S. Y., Prasad, K. M. N., Wu, T. Y., Raghunandan, M. E., Yang, B., Phang, S. M., \& Ramanan, R. N. (2017). Isolation, characterization and the potential use of starch from jackfruit seed wastes as a coagulant aid for treatment of turbid water. Environmental Science and Pollution Research, 24(3), 2876-2889. 
[11] Yan, S., Murthy, K., Prasad, N., Yeong, T., Eshwaraiah, M., Phang, S., \& Ching, J. (2017). Starch-based flocculant outperformed aluminium sulfate hydrate and polyaluminium chloride through effective bridging for harvesting acicular microalga Ankistrodesmus. Algal Research, (February), 0-1.

[12] Kakoi, B., Kaluli, J. W., Ndiba, P., \& Thiong'o, G. (2017). Optimization of Maerua Decumbent bio-coagulant in paint industry wastewater treatment with response surface methodology. Journal of Cleaner Production, 164, 1124-1134.

[13] Anju, S. (2016). Exploring the Use of Orange Peel and Neem Leaf Powder as Alternative Coagulant in Treatment of Dairy Wastewater, 7(4), 238-244.

[14] Oladoja, N. A., Saliu, T. D., Ololade, I. A., Anthony, E. T., \& Bello, G. A. (2017). A new indigenous green option for turbidity removal from aqueous system. Separation and Purification Technology, 186, $166-174$.

[15] Muthuraman, G., \& Sasikala, S. (2014). Removal of turbidity from drinking water using natural coagulants. Journal of Industrial and Engineering Chemistry, 20(4), 1727-1731.

[16] Takaoka, A., Baptista, A., Oliveira, M., Guttierres, R., Bergamasco, M., Fernandes, M., Vieira, S. (2017). Protein fractionation of seeds of Moringa oleifera lam and its application in superficial water treatment. Separation and Purification Technology, 180, 114-124.

[17] Camacho, F. P., Sousa, V. S., Bergamasco, R., \& Ribau Teixeira, M. (2017). The use of Moringa oleifera as a natural coagulant in surface water treatment. Chemical Engineering Journal, 313, 226237.

[18] Garde, W. K., Buchberger, S. G., Wendell, D., \& Kupferle, M. J. (2017). Application of Moringa Oleifera seed extract to treat coffee fermentation wastewater. Journal of Hazardous Materials, 329, 102-109.

[19] Katata-seru, L., Moremedi, T., Aremu, O. S., \& Bahadur, I. (2017). PT SC. Journal of Molecular Liquids.

[20] Ramavandi, B., Hashemi, S., \& Kafaei, R. (2015). A novel method for extraction of a proteinous coagulant from Plantago ovata seeds for water treatment purposes. MethodsX, 2, 278-282.

[21] Ribau Teixeira, M., Camacho, F. P., Sousa, V. S., \& Bergamasco, R. (2017). Green technologies for cyanobacteria and natural organic matter water treatment using natural based products. Journal of Cleaner Production, 162, 484-490.

[22] Shamsnejati, S., Chaibakhsh, N., Pendashteh, A. R., \& Hayeripour, S. (2015). Mucilaginous seed of Ocimum basilicum as a natural coagulant for textile wastewater treatment. Industrial Crops and Products, 69, 40-47.

[23] Abidin, Z. Z., Mohd Shamsudin, N. S., Madehi, N., \& Sobri, S. (2013). Optimisation of a method to extract the active coagulant agent from Jatropha curcas seeds for use in turbidity removal. Industrial Crops and Products, 41(1), 319-323.

[24] Kakoi, B., Kaluli, J. W., Ndiba, P., \& Thiong’o, G. (2016). Banana pith as a natural coagulant for polluted river water. Ecological Engineering, 95, 699-705.

[25] Yang, C., Yeong, T., \& Ching, J. (2014). Potential use of rice starch in coagulation - flocculation process of agro-industrial wastewater : Treatment performance and flocs characterization. Ecological Engineering, 71, 509-519.Kim HS \& Jeong HS (2007), A nurse short message service by cellular phone in type- 2 diabetic patients for six months. Journal of Clinical Nursing 16, 1082-1087.

[26] Antov, M. G., Śćiban, M. B., \& Petrović, N. J. (2010). Proteins from common bean (Phaseolus vulgaris) seed as a natural coagulant for potential application in water turbidity removal. Bioresource Technology, 101(7), 2167-2172.

[27] Debora, J., Theodoro, P., Lenz, G. F., Zara, R. F., \& Bergamasco, R. (2013). Coagulants and Natural Polymers: Perspectives for the Treatment of Water, 2(3), 55-62.

[28] Awad, M., Wang, H., \& Li, F. (2013). Research Article Weaknesses of Moringa oleifera Use in Water Treatment, 2-4. 